\title{
WUTHERING HEIGHTS IN THE POST CIVIL-WAR PERIOD: ANALYSIS AND EVALUATION OF THE TRANSLATION BY EL BACHILLER CANSECO (1947)
}

\author{
Ana Pérez Porras
}

Universidad de Jaén

\begin{abstract}
Wuthering Heights (1847), by Emily Brontë, has been translated into Spanish on more than one hundred ocassions 1 from an early date, although, prior to the academic and institutional development of translation studies around the midseventies, the translators faced a series of problems mainly due to lack of proper instruction and resources. The translation by El Bachiller Canseco (1947) is a paradigmatic example of these kinds of translations published during the Post Civil-war Period in which the translator did not have any specific training or access to specialised monographs. This lack of training had an impact on the resulting target text, since his translation did not succeed at transferring Brontë's cultural implications. To transfer them correctly, the historical-social context of the work would need to have been studied in great detail. In the text, we are witness to the translator's intervention, something that we can observe in the omissions, errors and examples of interpretative translation. El Bachiller Canseco appears not to have known the sources of the original text, nor was he able to draw a line between his facets as a writer and translator. It is particularly regrettable that a modern retranslation of translations of the aforesaid period has not been conveniently revised and updated, as Canseco's recent retranslation (Edimat 2009) clearly exemplifies.
\end{abstract}

Keywords: Emily Brontë, Wuthering Heights, El Bachiller Canseco, literary translation, post civil-war, retranslation

\section{Resumen}

Wuthering Heights (1847), de Emily Brontë, ha sido traducida al español en más de un centenar de ocasiones. La traducción de El Bachiller Canseco (1947) se publicó por primera vez tras el periodo de la guerra civil en el que el traductor no contaba con una formación específica ni tampoco tenía acceso a monografías

\footnotetext{
${ }^{1}$ See Pajares Infante (84-91); see also Datos Biblioteca Nacional de España (DATOS.BNE.ES *beta version), which gives 177 editions.
} 
especializadas. Esta falta de formación repercute en el texto meta, puesto que el traductor no consigue trasladar el las implicaciones culturales de Brontë. Para trasladarlo correctamente habría sido imprescindible estudiar detenidamente el contexto histórico-social de la obra. En el texto somos testigos de la intervención del traductor, algo que podemos constatar por las omisiones, errores y ejemplos de traducción interpretativa. El Bachiller Canseco no parece conocer las fuentes del texto original ni encuentra tampoco el límite entre su faceta de escritor y traductor. En concreto, es lamentable que una retraducción moderna de las traducciones de la citada época no se haya revisado ni actualizado pertinentemente, como ejemplifica notoriamente la reciente retraducción de El Bachiller Canseco (Edimat 2009).

Palabras clave: Emily Brontë, Cumbres Borrascosas, El Bachiller Canseco, traducción literaria, posguerra civil, descriptive

\section{The retranslation of Wuthering Heights in Spain: the case of El Bachiller Canseco (1947)}

Wuthering Heights was not known in Spain until 1921, when it began to spread with the first translation by Cebrià de Montoliu in the Atenea Publishing House. From 1921 to 1942 no new translations were recorded in the catalogue of the National Library. In that very year and in the following ones, however, a series of translations followed in what is known as the Post-civil War Period in Spain, as can be seen in the list below (Gil García 104):

\footnotetext{
- 1941. Miguel Pérez Ferrero². Madrid: La Nave Publishing House.

- 1941. Juan González-Blanco de Luaces: Destino.

- 1944. Javier Zengotita. Barcelona: Reguera.

- 1944. Fernando Durán. Barcelona: Juventud.

- 1945. Luis Conde Vélez. Barcelona: Bruguera.

- 1945. Andrés Caballero. Barcelona: Vives.

- 1947. El Bachiller Canseco. Madrid: Aguilar.
}

The first applications from the Archivo General de la Administración (AGA) that collect data about Cumbres Borrascosas in the Francoist period were consulted by Pajares Infante (74), and, according to his research, the translations were not subjected to any impediment by the censor system. Therefore, we will

\footnotetext{
${ }^{2}$ Miguel Pérez Ferrero (1905-1978) is known for his masterpiece, the biography of the Machado brothers (1947). In 1923 he published his first book of poetry. In 1945 he began his career as a journalist in ABC and Blanco y Negro. Some of his works are Vida de Pío Baroja (1972), Unos y otros (1947) and Tertulias y grupos literarios (1975).
} 
not deal with this aspect of the transmission of Wuthering Heights in the present article.

In the case of the 1947 translation published by Aguilar, the translator hides behind the pseudonym of El Bachiller Canseco and to this day his identity has not been discovered. He possibly formed part of the translation staff in the Aguilar Publishing House, as he translated Inés Grey (1974) with María Fernanda de Pereda and Amando Lázaro Ross ${ }^{3}$.

According to Tello Fons (388), only a few years passed in which no edition of the novel was published, and the number of translations increased notably in the $1980 \mathrm{~s}$ and $1990 \mathrm{~s}$ and in the first decade of the $21^{\text {st }}$ century ${ }^{4}$. Different researchers, such as Gil García (1993), Pajares Infante (2007), Santoyo (1980) and López Folgado ("Las traducciones" 156-159), denounced a notable similarity between translations and Spanish editions. In addition to this notable similarity, in the contemporary publishing market we find translations from the Postwar period which have been republished. These are the cases of Juan González Blanco de Luaces (1942) $)^{5}$, republished by Aldevara in 2010 (Ortega Sáez 2013), and El Bachiller Canseco (1947). The latter has been compared by López Folgado ("Cumbres Borrascosas" 234) with the recent translation issued by Edimat Publishing House (2009), in which the only mention to the translator is a cryptic "Equipo Editorial" (Publishing Team). López Folgado convincingly shows that it is identical to El Bachiller Canseco's translation. This is the reason why we have selected the original translation published in 1947 for our study, as it constitutes a typical case of retranslation in which all the errors and shortcomings, some of which will be duly pointed out in the present article, have been kept.

\section{Theoretical framework}

\subsection{Toury: translations as facts of culture}

Gideon Toury, the same as his colleague at the University of Tel Aviv, Itamar Even Zohar (1990), developed his theory on translation departing from Russian Formalism and Prague Structuralism. In the course of time, however, he generated his own original theory, which we could loosely term descriptive translation studies. In effect, in his seminal work Descriptive Translation Studies and Beyond (1995), he adapted the concept of polysystem (originally developed by Even

\footnotetext{
${ }^{3}$ Pajares Infante (65) explains that he did not manage to decipher the pseudonym of "El Bachiller Canseco".

${ }^{4}$ See the Spanish National Library catalogue: http://catalogo.bne.es/uhtbin/webcat

${ }^{5}$ The translation by G. de Luaces (1942) is part of our current publishing market since the Aldevara publishing house launched an edition in 2010.
} 
Zohar) and proposed a new translation theory, in which translation was defined as follows:

... any target-culture text for which there are reasons to tentatively posit the existence of another text, in another culture/ language, from which it was presumably derived by transfer operations and to which it is now tied by a set of relationships based on shared features, some of which may be regarded-within the culture in question -as necessary and/ or sufficient (Toury 30-31).

The comparison with the source text helps to determine the differences and relations between both cultures, as well as the different mechanisms operating in the literary polysystems and the concept of translation prevailing in each of these. We must start from the premise that the translator is undertaking a social work, since translation acquires a cultural function, and therefore, will follow rules implemented by this community in question: "Norms have long been regarded as the translation of general values or ideas shared by a community -as to what would count as right or wrong, adequate or inadequate- into performance 'instructions' appropriate for and applicable to concrete situations" (Toury 63).

One of Toury's aims was to generalise trends in translators' behaviour and develop a series of rules. Firstly, the "initial rule" defines whether the translator will yield to the "rules" of the target culture. This determines two other key terms within the polysystem theory: "adequacy" and "acceptability" (70). It is precisely in this target system where the translated text will function, where its rules tend to prevail and its concept of translation (tied to other factors) will influence the degree of adequacy and acceptability of the translated texts.

Toury states that "translations are facts of target cultures; on occasion facts of special status, sometimes even constituting identifiable (sub)systems of their own, but of the target culture in any event" (29). This definition is relevant since firstly, it understands translation as a cultural phenomenon, and secondly, it establishes that this phenomenon belongs to the target culture. It also shows that this phenomenon, in addition to belonging to the target culture, does not follow the source-target direction in the translation process. As the author states: “... every text is of course unique; it may be more or less in tune with existing texts and prevailing models, but in itself it is a novelty" (22). As a point of reference, Toury's proposal takes different factors that should be considered, such as the historical context or place. 


\subsection{Translation methods and techniques}

According to Hurtado Albir (2001), the translator's method is governed by principles determined by the purpose of the translation and by the context (249). The choice of method involves the use of specific translation techniques (Hurtado Albir 254-56). For that reason, we must therefore establish a relationship between the translation methods and techniques. According to the author, the option selected will determine the use of certain techniques or others. Thus, according to Hurtado Albir, "with a methodological option that prioritises the adaptation method, reduction, amplification, generalisation, description, adaptation, discursive creation, etc. will prevail" (254). Molina Martínez, acknowledging that techniques have "a functional and dynamic nature" (100), insists on the idea that the translator will use one or another technique depending on the purpose of the translation, type, method and genre of the text (113).

Two main methods can be used by the translator, as proposed by Venutti: the domestication method or the foreignization method. The latter consists in the orientation of the TT towards the language and culture of the ST, ${ }^{6}$ whereas the former is understood as the acclimatization of cultural and linguistic elements to the target language and culture, or as Venuti puts it:

... the reconstitution of the foreign text in accordance with values, beliefs and representations that preexist it in the target language, always configured in hierarchies of dominance and marginality, always determining the production, circulation, and reception of texts. Translation is the forcible replacement of the linguistic and cultural difference of the foreign text with a text that will be intelligible to the target-language reader (18).

This is perfectly in line with Even-Zohar's (46-49) translation theory, which posits that translated literature is a system which normally occupies a peripheral place in the Target Polysystem unless the Polysystem is young and in process of creation. This idea was further elaborated by Toury (1995) in his law of growing standardization. In Toury's theory, in a translation the textual relationships among the different elements of the ST are usually modified in favour of more habitual options in the TT (304), with the final corollary, relying on Even-Zohar's thesis of the peripheral place of translated literature, that "the more peripheral this status [of translated literature], the more translations will accommodate itself to established models and repertoire [in the TT]" (307). From here we can postulate

\footnotetext{
${ }^{6}$ From now onwards TT will stand for Target Text and ST for Source Text.
} 
that the general background of a Post-Second World War and more conservative pre-1968 Europe, ${ }^{7}$ and the particular atmosphere of repression fostered by the Dictatorship and its particular version of National Catholicism in Spain created the conditions for a placement of foreign literature within a peripheral position in the Spanish social and cultural polysystem. Consequently, as defended in this study, the translator is overtly bent on the domestication method, understood as the acclimatization of cultural and linguistic elements to the target language and culture, since the purpose of domestication is to remove any hindrance or demand on the TT reader concerning the source culture and therefore obtain a TT that is as accessible and as easy to read as possible for readers of the target culture. Domestication, however, as the present case shows, may be also due to a will to eschew problems of translation due to lack of competence and/or means on the part of the translator.

We have developed a translation analysis with the aim of stressing the importance of retranslation in the case of a classical Victorian novel that has been periodically translated in Spain for almost a century. For our analysis we have chosen a small selection of translemes (Santoyo, "A propósito" 258-61). All the selected chapters focus on prominent themes in the novel: death (Spear 18), revenge (Bhattacharyya 156) and orphanhood (Thompson 1963).

\section{Analysis and evaluation}

For the taxonomy of our analysis we have chosen to narrow and refine the general categories of Hurtado Albir (reduction, amplification, generalisation, description, adaptation, discursive creation, etc.) resorting to the more specific operations proposed by Valero Garcés (136), which we believe to be consistent and more productive within both the methods and categories exposed above. These operations are: (1) Changes due to socio-cultural differences, (2) Tone variation; (3) Internal structure variation of the original, (4) Moderation of expressions, (5) Inadequate equivalences, (6) Deletion of the marginal account, (7) Conservation of proper names with equivalence in the ST, (8) Translator's error, (9) Conservation of original text structures/ literal translation; (10) Elaboration versus simplification, and finally (11) Variation in the use of literary figures and tropes (Valero Garcés 136). Of these operations, we have focused on the following ones as being more indicative of the translation problems depending on discursive

\footnotetext{
${ }^{7}$ We take 1968 and its famous May protests in France (echoed in other countries of the Western World) as a conventional landmark which triggered the social, sexual and political changes towards a more progressive change in sensibility in Europe.
} 
contextualization and especially affected by the material and ideological precariousness of the Post-war Period translations:

- Changes due to socio-cultural differences: the novel demands an exhaustive knowledge of Victorian and Yorkshire culture. To illustrate this aspect, we have followed Igareda's classification (19-21) and selected 4 cultural references related to Brontë's socio-cultural context.

- Deletion of the marginal account: many omissions have been found in the TT. They may be due to the fact that the translator had to work on many translation assignments at the same time. We have analysed chapters 1, 4 and 6 of volume II.

- Translator's errors: in the Post-war Period, access to information sources, specialised publications and dictionaries was much more limited than more recent times. We have focused on chapters 5 and 8 of volumen I and 2 and 16 of volumen II.

- Inadequate equivalences: in this section we have gathered the examples in which the translator deviates from the content of the ST and from the author's intention. We have selected chapters 1,3 and 8 of volume II.

The comparative analysis helps to observe the differences between the ST and the TT. As the original text we chose the first published edition of Wuthering Heights, a novel, in three volumes ${ }^{8}$ (Brontë and Brontë 1847), in 2 volumes. The aim of this study is to analyse and evaluate the translation by El Bachiller Canseco which was republished by Edimat (2009-2012). In this evaluation of the text we will analyse the cultural references ${ }^{9}$ of the work in the context and the techniques followed by the translator with a view to prove the advanced hyptothesis that he approached the domestication method and that it was due mainly to the conditions of the polysystem of reception and (censorships excepted) the precariousness of Post-war means and resources. After the analysis, we will propose an evaluation of the translation.

\subsection{Changes due to socio-cultural differences}

Before tackling the traductological analysis, it becomes necessary to study the historical-social context in which the author was immersed. Franco Aixelá stresses the traductological conflictivity of cultural elements: "Those textually actualized items whose function and connotations in a source text involve a translation problem in their transference to a target text, whenever this problem is a product of the nonexistence of the referred item or of its different intertextual

\footnotetext{
${ }^{8}$ This is a transcription of the first edition of Wuthering Heights, of only the first two volumes corresponding to E. Brontë's novel. The third volume corresponds to the novel by Anne Brontë, Agnes Grey.

${ }^{9}$ For an analysis of the translation of cultural references in audiovisual texts see Díaz-Pérez.
} 
status in the cultural system of the readers of the target text" (58). According to Pérez Porras, "E. Brontë's sole novel contains a wealth of cultural, mythological, or literary information which cannot be fully comprehended in a different culture unless it is transferred through appropriate translation techniques and solutions" (Análisis comparativo 422). As regards cultural terms ${ }^{10}$, we have selected some cultural items from the ST that refer to the social and cultural context of the author. To arrange the references we took Newmark's (95-103) and Igareda's classifications of cultural categories (Fauna, Social universe, Social models and Respected figures) (19-21) as a reference.

Furthermore, we have consulted modern translations of the contemporary editorial market.

\subsubsection{Fauna (ornithology)}

Brontë was devoted to birds and she expressed this in her work; in it we find larks, linnets, cuckoos (Astor Guardiola 350). At the age of 11, Brontë copied an engraving from Thomas Bewick's History of the British Birds, 2 vols., 1797-1804 (Lavín Camacho 273) entitled The Winchat (Alexander \& Sellars 371). It seems that she inherited this interest in ornithology from her father, Patrick Brontë. He was determined for his children to develop their artistic skills and enrolled the four siblings in painting classes with John Bradley from 1829-30 (Ingham xiii). Mr Brontë seemed to be interested in the natural world and had three volumes with which his children were familiar: A History of British Birds (1797-1804), by Thomas Bewick, Ornithological Biography, and An Account of the Habits of the Birds of the United States of America, by the North-American ornithologist John James Audubon (1831-1839) (Barker, The Haworth Context 24).

In chapter 12 of Wuthering Heights (vol. I), the reader comes across two specific cases in which an indirect reference is made to the popular legends of the time. The readers' understanding of the first half of the chapter depends greatly on their knowledge of the history and folklore of the Yorkshire region:

\begin{tabular}{|l|l|c|}
\hline \multicolumn{1}{|c|}{ ST } & REF. \\
\hline $\mathbf{1 8 4 7}$ & $\begin{array}{l}\text { 'That's a turkey's,' she murmured to herself; 'and this } \\
\text { is a wild duck's; and this is a pigeon's. Ah, they put } \\
\text { pigeons' feathers in the pillows - no wonder I couldn't } \\
\text { die! Let me take care to throw it on the floor when I lie }\end{array}$ & $\begin{array}{c}\text { (I, 12, } \\
175)\end{array}$ \\
\hline
\end{tabular}

\footnotetext{
${ }^{10}$ For a more detailed study of the translation of cultural references in the work see chapter five of Pérez Porras's PhD thesis (Análisis comparativo 2015).
} 


\begin{tabular}{|l|l|l|}
\hline & $\begin{array}{l}\text { down. And here is a moor-cock's; and this - I should } \\
\text { know it among a thousand - it's a lapwing's. }\end{array}$ & REF. \\
\hline EL BACHILLER CANSECO & $\begin{array}{l}\text {-Esta es de pavo - murmuraba para sí-, y ésta de } \\
\text { pato salvaje, y ésta de pichón. iClaro: cómo voy a } \\
\text { morirme si me ponen plumas de pichón en las } \\
\text { almohadas! Pero cuando me acueste, las tiraré. Ésta es } \\
\text { de cerceta, y ésta de avefría. La reconocería entre mil: } \\
\text { este pájaro solía revolotear sobre nuestras cabezas } \\
\text { cuando íbamos por medio de los pantanos. }\end{array}$ & (12,139) \\
\hline $\mathbf{T 9 4 7}$
\end{tabular}

Through these birds' feathers, Brontë introduces us to the dark world of death and superstition. During the first half of the $19^{\text {th }}$ century, the mere appearance of pigeon feathers, in a context in which death played an essential role, clearly implied a negative connotation. On these occasions, it was assumed that the persons on their deathbed would never be freed of their suffering, nor could they have a pleasant death if the pillow or mattress on which they were lying contained bird feathers, or worse still, pigeon feathers. Often, when the ill were suffering, they were lifted off the bed on the supposition that there were pigeon feathers in the mattress, thereby trying to make their death as pleasant as possible (Pérez Porras, Análisis comparativo 86-87). For this reason, Catherine Linton's behaviour comes as no surprise, when, a prisoner to delirium after tearing the pillow with her teeth, she "... seemed to find childish diversion in pulling the feathers from the rents she had just made, and ranging them on the sheet according to their different species" (I, 12, 275), since this image can be interpreted as the impossibility of dying because of the feathers in the pillow. This popular belief can be summarised in Richard Blakeborough's words: "the soul cannot free itself if the dying person has been laid on a bed containing pigeon feathers, or the feathers of wild birds even" (Blakeborough 116). The muteness of the Spanish text as to this cultural implication leaves the readers clueless as to certain attitudes of the characters. This is a problem which in modern times has not been salvaged by the insertion of footnotes, a point in which the role of translator and editor crisscross. It is our opinion, in this sense, that in works containing a certain degree of diachrony such as to require an explanation for the modern native English speaker, the translator should resort to editorial techniques. The non-existence of a similar cultural implication in 1947 or in 2009 Spain demanded an explanation, which makes it difficult to understand why a thorough revision of this issue has not been undertaken in the 2009 edition. 
Another interesting case is that of the term moor-game, which is presented below:

\begin{tabular}{|c|l|c|}
\hline \multicolumn{1}{|c|}{ ST } & REF. \\
\hline $\mathbf{1 8 4 7}$ & $\begin{array}{l}\text { 'Well,' said I, 'where are your moor-game, Miss } \\
\text { Cathy? We should be at them: the Grange park-fence } \\
\text { is a great way off now.' }\end{array}$ & $\begin{array}{c}\text { (II, 7, } \\
132)\end{array}$ \\
\hline \multicolumn{1}{|c|}{ EL BACHILLER CANSECO } & REF. \\
\hline $\mathbf{T T})$ & $\begin{array}{l}\text {-iPero bueno! -dije yo-. ¿Dónde están esos } \\
\text { pájaros de que habla, señorita? Ya tendríamos que } \\
\text { haberlos vistos; la valla del parque de la Granja ha } \\
\text { quedado ya muy atrás. }\end{array}$ & (21,327) \\
\hline
\end{tabular}

Nelly Dean explains that the young sixteen-year-old Cathy Linton, who is not aware of the story about her mother and Heathcliff, has grown up over-protected by her father Edgar Linton. For the young woman, walks in the countryside and contact with the birds on the moors were the most pleasant ways to spend a hot July day. On one of these innocent walks in the moors with Nelly, looking for birds' nests, Cathy meets her cousin Linton Heathcliff.

About the word moor-game, the OED specifies that it refers to a red/black grouse: "n. now Brit. regional (a) the red grouse, Lagopus lagopus; (b) the black grouse, Tetrao tetrix (rare)" (Simpson and Weiner 2004). Lavín Camacho's monolingual edition of Wutthering Heilghts also includes information about this species: "moor-game: red grouse" (242). In the target culture there is only a scientific nomenclature counterpart (lagópodo escocés), and therefore, the translator must use specific techniques to correctly transfer the reference in a literary context. In this case, by resorting to the generalisation technique, the translator did not manage to transfer the characteristics of the ornithological species. The problem of the transference of this element of material culture is not easy to solve if we take into account that the familiarity with the bird in the moorland that Emily Brontë describes (should it be the moor around Haworth where Emily spent most of her life, the Shibden valley where she worked, or the countryside near Cowan Bridge where she lived briefly as a child) ${ }^{11}$ has no correspondence for the Spanish reader. Using the taxonomic name (lagópodo escocés) would have meant an outrageous breach in linguistic register, since the scientific and literary discourses would be mixed in an incompatible way. On the other hand, the solution provided by El Bachiller Canseco abounds in the process of domestication but leaves out important nuances of both connotation and

${ }^{11}$ See Readers's Guide to Wuthering Heights https://goo.gl/VrXiuh 
denotation. It is relevant to analyse how two modern translators - Castillo (1996) and D'Amonville Alegría (2012) - have solved the problem. The first translator provides "cercetas" (234) and opts for domestication. In turn, the second one, D'Amonville Alegría selects "perdices escocesas" (262). As a possible solution we suggest the use of adaptation and description techniques converging in the term "perdiz roja escocesa" or just "perdiz roja".

\subsubsection{Social universe (traditions)}

In the novel, popular traditions are exhibited at times, as occurs in chapter 7, in which Catherine Earnshaw returns home, to Wuthering Heights on Christmas Eve, after having spent several weeks ill in the Lintons' home. On her arrival, and after the attentive flattery she receives from her family, Nelly "after playing lady'smaid to the new-comer, and putting my cakes in the oven, and making the house and kitchen cheerful with great fires, befitting Christmas-eve" (I, 7, 118), retires to enjoy herself "by singing carols, all alone" (I, 7, 118).

\subsubsection{Glees}

\begin{tabular}{|c|c|c|}
\hline \multicolumn{2}{|r|}{ ST } & REF. \\
\hline 1847 & $\begin{array}{l}\text { They go the rounds of all the respectable houses, and } \\
\text { receive contributions every Christmas, and we } \\
\text { esteemed it a first-rate treat to hear them. After the usual } \\
\text { carols had been sung, we set them to songs and glees }{ }^{\mathbf{2}} \text {. } \\
\text { Mrs. Earnshaw loved the music, and so they gave us } \\
\text { plenty. }\end{array}$ & $(\mathrm{I}, 7,33)$ \\
\hline \multicolumn{2}{|r|}{ EL BACHILLER CANSECO } & REF. \\
\hline $\begin{array}{l}\text { (TT) } \\
1947\end{array}$ & $\begin{array}{l}\text { Hacen recorrido de todas las casas importantes y } \\
\text { reciben buenos aguinaldos por Navidad. Primero cantan } \\
\text { villancicos, y luego, para satisfacer a la señora } \\
\text { Earnshaw, que era muy amante de la música, tocaron } \\
\text { gran número de piezas. }\end{array}$ & $(7,81)$ \\
\hline
\end{tabular}

On several occasions, Brontë introduces these musical traditions through the character of Nelly, who in this same chapter refers to another tradition, in this case a local one: the typical musical bands in the social life of West Riding, which on festive occasions such as Christmas, delighted people with their music. Nelly

\footnotetext{
${ }^{12}$ Lavín Camacho (91) points out that Glee is an "English song, for three or more voices, similar to the madrigal, generally without any musical accompaniment".
} 
states: "They go the rounds of all the respectable houses, and receive contributions every Christmas, and we esteemed it a first-rate treat to hear them" (I, 7, 131). The $O E D$ provides the following definition of glee:

A musical composition, of English origin, for three or more voices (one voice to each part), set to words of any character, grave or gay, often consisting of two or more contrasted movements, and (in strict use) without accompaniment. The glee differs from the madrigal in involving little or no contrapuntal imitation, and from the part-song in the independence of its parts, which form 'a series of interwoven melodies' (Simpson and Weiner 2004).

This small musical inclusion that Brontë makes in the chapter can be considered as an allusion to the busy cultural life of Haworth, needless to say incomparable to that in the country's large cities, but still of great value and importance. It must not be forgotten that "Haworth in the period from 1820 to 1861 was a community with cultural aspirations and, perhaps more surprisingly, a venerable musical tradition" (Baker, The Haworth context 21). El Bachiller Canseco (1947) omits the cultural reference. In our opinion, it would be advisable to include an explanatory footnote as Castillo (1996) has done. She justifies her selection and explains that "madrigales" is the most similar term in Spanish (191). In our judgement, D'Amonville Alegría's proposal, "coplas" (77), does not transmit Brontë's cultural heritage. The use of paratexts is essential, in our view, in order to understand the cultural complexity of the novel. Sometimes, however, publishing houses prefer to make the narration sharper for the reader and avoid the use of paratexts.

\subsubsection{Social models and respected figures}

Within this sub-section we shall analyse the words sizar and magistrate. Firstly, sizar refers to the figure of Patrick Brontë. Emily's father obtained a place as sizar in St. John's College (Cambridge) thanks to a recommendation from Reverend Thomas Tigue, a wealthy landowner: "To be admitted, all that he required were letters from Thomas Tigue attesting to his ability, conforming that he had reached the necessary standard of education and recommending him for an assisted place as sizar" (Barker, The Brontës 6). At the age of twelve, Patrick Brontë tutored the Reverend's son and the latter was impressed by his work. The patriarch managed to attend Cambridge, an extraordinary privilege for a young man from the peasant class. Emily Brontë presents the perfectly visible division of classes both in $19^{\text {th }}$-century urban England and in rural England, emphasising 
the importance of the highly hierarchized structure in the Victorian society. This classist society is notable for the inequality observed in its different strata, where changes were gradually introduced, which made the former class system, perfectly rooted in the past, break down along the gradual triumph of the middle class, represented in the novel by Heathcliff.

\subsubsection{Sizar}

\begin{tabular}{|c|c|c|}
\hline \multicolumn{2}{|c|}{ SOURCE TEXT (1847) } & REF. \\
\hline $\mathbf{1 8 4 7}$ & $\begin{array}{l}\text { Did he finish his education on the Continent, and come } \\
\text { back a gentleman? or did he get a sizar's place at college }\end{array}$ & $($ I, 10, 52) \\
\hline \multicolumn{2}{|r|}{ EL BACHILLER CANSECO (1947) } & REF. \\
\hline $\begin{array}{l}\mathbf{( T T )} \\
\mathbf{1 9 4 7}\end{array}$ & $\begin{array}{l}\text { ¿Terminó su educación en el continente y volvió hecho } \\
\text { un caballero, o bien obtuvo una beca en un colegio, ... }\end{array}$ & $(10,114)$ \\
\hline
\end{tabular}

After spending three years in unknown whereabouts, Heathcliff manages to climb the social and economic ladder although it is never revealed how he does so. The uncertain origin of this character, and the fact that nothing is revealed at any time in the literary work despite the allusions made to him, sets out an evident problem from the beginning of the novel. The history of Heathcliff seems to interest Lockwood, who asks Nelly to continue the story. El Bachiller Canseco (1947) opted for generalisation; the solution provided does not correspond to the position in question ${ }^{13}$. It is important to note that the students who held this position had the opportunity to study in Cambridge or Trinity thanks to the economic assistance they received from the universities $(O E D)$. To correctly explain the meaning of the references to the target reader, we would suggest the use of a footnote, although this decision depends on publishing imperatives. Castillo (1996) opted for a foreignizing method, "sizar", and added an explanatory footnote (222-23). According to Pérez Porras, "Castillo (Brontë, 1989) studies the novel thoroughly and adds explanatory footnotes, with a very clear objective in mind: to bring the target text reader closer to the ST and to Victorian culture" (Análisis comparativo 421) D'Amonville Alegría's solution (2012), "becario" (115), is insufficient in our opinion. We propose to combine generalization and description techniques: "becario de Cambridge/ Trinity College".

\footnotetext{
13 To correctly explain the meaning of the references to the target reader, we would suggest the use of a footnote, although this decision depends on publishing imperatives.
} 


\subsubsection{Magistrate}

\begin{tabular}{|c|l|c|}
\hline \multicolumn{1}{|c|}{ ST (1847) } & REF. \\
\hline $\mathbf{1 8 4 7}$ & $\begin{array}{l}\text { To beard a magistrate in his strong-hold, and on the } \\
\text { Sabbath, too! where will their insolence stop? Oh, my } \\
\text { dear Mary, look here! }\end{array}$ & (I, 6, 108) \\
\hline \begin{tabular}{l|l|} 
EL BACHILLER CANSECO (1947) \\
$\mathbf{1 9 4 7}$
\end{tabular} & $\begin{array}{l}\text {-iAtacar a un magistrado en su propio domicilio y en } \\
\text { domingo, además! }\end{array}$ & $\mathbf{R E F}$ \\
\hline
\end{tabular}

The two protagonist families in the story, the Earnshaws and the Lintons, represent different social groups. Catherine, with the desire to aspire to a better position than that held by her family, can be considered the main cause of the social conflict generated in the novel. Bearing in mind the following statement from Thompson, "In an ambitious family, resources could be mobilized behind the daughters, the instruments of family advance" (English Landed Society 100), the character of Catherine is understood as a true instrument in the struggle to climb in society. Her attitude and behaviour reflect an evident awareness of class. From a social point of view, the Linton family occupies a higher rank than the Earnshaws in the classist society, as they are members of the gentry, the upper middle class.

We know that Mr Linton is a magistrate, a position which his son Edgar takes on when his father dies, thereby assuming the same responsibilities that had previously been held by his father. The reader is aware of this fact in chapter 6 (volume I), when Heathcliff and Catherine are discovered stalking the Linton family through the windows of their house. It is then that Mr Linton utters "to beard a magistrate in his stronghold, and on the Sabbath, too!" (I, 6, 108). The fact that Edgar Linton inherits the position of magistrate from his father means that he possesses some legal knowledge, which explains his determination to consider the possibility of modifying his will, with the idea of specifying the enjoyment of the belongings which can solely and exclusively be accessed by his daughter Cathy and her successive descendants, should she have any.

It is important, then, not to confuse the legal English word magistrate with the Spanish noun magistrado, which is the solution provided by El Bachiller Canseco (1947), since the meanings of these words do not correspond. Although this is a case of translator's error and could have been included in the corresponding section below, I have preferred to keep it here since it is also an example of undue generalization due to a lack of a clear cultural equivalent in 
Spanish, since the institutional relevance and functions of a justice of the peace does not correspond with a "juez de paz" either. While the English magistrate is a justice of the peace, magistrado in Spanish refers to a Higher Judge (Alcaraz Varó 333). Modern translations commit the same mistake. Thus, in our contemporary editorial market, Castillo (64) and D'Amonville Alegría (64-65) propose "magistrado".

\subsection{Deletion of the marginal account}

In the TT, we frequently find omissions which do not affect the main plot, although they do reduce the emphasis of the characters' dialogue or the descriptions. The exhaustive analysis of the original text and the present version reveal different types of omissions. These omissions could be justified if the translator needed to finish several assignments in order to survive.

\section{SOURCE TEXT (1847)}

(1). 'I shouldn't care what you suffered. I care nothing for your sufferings. Why shouldn't you suffer? I do!

(II, 1, 9)

(2). 'She's fainted, or dead,' I thought: 'so much the better. Far better that she should be dead, than lingering a burden and a miserymaker to all about her.

(II, 1, 19)

(3). Mr. Heathcliff, I believe, had not treated him physically ill; thanks to his fearless nature which offered no temptation to that course of oppression;

(II, 4, 94-85)

(4) "You are my son, then I'll tell you; and your mother was a wicked slut to leave you in ignorance of the sort of father you possessed---Now, don't wince, and colour up!

(II, 6, 120-121)

\section{EL BACHILLER CANSECO}

(1947)

— ¡No me importa que sufras! ¡No me importan tus sufrimientos! $[\varnothing]_{i} Y_{0}$ también sufro!

"Está desmayada o muerta -pensé--. Tanto mejor. Mejor todavía que se haya muerto, antes que convertirse en una pesada carga $[\varnothing]$ para todos los que la rodean

Según creo, Heathcliff no se ensañó con él en maltratarle físicamente, $[\varnothing]$ y sólo desahogó su malevolencia procurando hacer de él un ser ignorante, ...

$(18,222)$

-Eres mi hijo y, por tanto, te digo que tu madre ha sido una malvada [Ø] al dejarte en la ignorancia de que tienes un padre. Ahora, no te sobresaltes ni te sonrojes ...

$(20,232)$ 
The first passage describes Catherine's death, one of the most dramatic scenes in the novel. For Marsh, Catherine's death is a challenge for the couple (61). When she disappears, her existence will become a real torture for Heathcliff. We find omissions in the characters' dialogue. Catherine Linton tries to make Heathcliff understand that his suffering does not worry her and that he should suffer as much as she (example 1). After this scene, Catherine faints. Faced with this painful situation, Nelly thinks it is best that she dies, rather than continuing to be a burden and a misery-maker. In example 2 misery-maker is omitted. As a more accurate solution, we propose Castillo's translation (1996): "motivo de desdichas" (211). Nelly Dean also refers to the Hareton's situation. Heathcliff offers to convert Hareton into what Hindley had converted him. We can observe that the translator preferred to delete information from the text, in this case "thanks to his fearless nature" (number 3); thanks to Nelly Dean, we know that it is precisely his fearless nature that prevents the mistreatment. Both Hareton and Linton Heathcliff grow up without a mother figure. Thompson highlights the violence and cruelty with which children are treated in the novel: “... the world of Wuthering Heights is a world of sadism, violence, and wanton cruelty, wherein the children-without the protection of their mothers-have to fight for their very life against adults who show almost no tenderness, love, or mercy" ("Infanticide" 71). In our judgement, the solution suggested by Castillo (1996) - "gracias a su carácter osado" (328)and D'Amonville Alegría (2012) - “porque la naturaleza intrépida” (241-42) - are correct. In this fragment, Heathcliff taints the memory of Isabella, using very pejorative language, with the aim of hurting his son. It is also relevant to point out the omission of slut in example 4. The $O E D$ defines slut as "[a] woman of dirty, slovenly, or untidy habits or appearance; a foul slattern" (Simpson and Weiner 2004). As a solution we suggest "una malvada pazpuerca".

\subsection{Translator's error}

In this section we have selected some examples in which due to an incorrect interpretation, the meaning of the text has changed. Some of these errors are due to the lack of consulting specialised dictionaries.

\section{SOURCE TEXT (1947)}

(1). 'Your pride cannot blind God! You tempt him to wring them, till he forces a cry of humiliation.'

(II, 2, 27)
EL BACHILLER CANSECO

(1947)

¡Tu orgullo no puede engañar a Dios! Intentas desafiarle hasta que Él te arranque un grito de humillación".

$(16,91)$ 
(2). I felt to him in such a variety of ways, that it could have been impossible to have accosted him rationally".

(II, 16, 315)

(3). At last, our curate (we had a curate then who made the living answer by teaching the little Lintons and Earnshaws, and farming his bit of land himself) advised that the Young man should be sent to college;...

\section{(I, 5, 88)}

(4). "Oh, such a grand bairn!" she panted out. "The finest lad that ever breathed! But the doctor says missis must go; he says she's been in a consumption these many months.

$$
\text { (I, 8, 139-140) }
$$

Tan atropellados eran mis pensamientos en su presencia que me hubiera sido imposible hablarle de una manera racional.

\section{$(33,346)$}

Por aquellos días nuestro cura (teníamos entonces un cura que se ganaba la vida dando clase a los pequeños Lintons y Earnshaw y cultivando él mismo su trocito de tierra), aconsejó que el muchacho Hindley fuera al colegio.

— ¡Oh, qué criatura tan hermosa jadeó-. El niño más hermoso que he visto en mi vida! Pero el doctor dice que la señora se morirá, porque está enferma del pecho desde hace muchos meses.

Nelly informs Heathcliff about Catherine's death. The only way to possess her will be through death, provoking Heathcliff's obsession with the deceased woman. Heathcliff yearns for a reunion with his beloved which can only take place through death, as stated by Bhattacharyya (73): "Towards the end of his life Heathcliff longs for his reunion with Catherine, only through death". In this case, Nelly Dean tells the character that his pride cannot blind God. We find equivalence errors that may be due to the translator not consulting a dictionary or making a free choice. This can be observed in the first example, in which the correct equivalent for blind is not selected. Our proposed solution is "tu orgullo no puede deslumbrar a Dios". Catherine's ghost will follow Heathcliff. Soon before his death Heathcliff does not recognise Hareton as human, but as a personification of his youth. His incredible resemblance to Catherine leads him to associate him with her in a shocking way. El Bachiller Canseco (1947) does not select the equivalent for accost (see example 2) which means "abordar" or "importunar". We also find a false friend error (number 3). With this word, Brontë once again refers to the father figure, since Patrick Brontë was appointed the position of perpetual curacy in the Haworth Rectory (Paddock and Rollyson 48-49). Castillo (1996) proposes a proper equivalent: "coadjutor" (54). In example 4, the translator does not select 
the correct equivalent for consumption, which refers to tuberculosis. In modern translations, Castillo (1996) provides "que ha estado tuberculosa" (70), whereas D'Amonville Alegría (2012) also proposes a correct translation: “consumiéndose de tisis" (82).

\subsection{Inadequacy of equivalences}

In this case, we are also referring to the content of expressions that were distorted by the use of unnecessary amplifications, as a result of the translator's intervention. El Bachiller Canseco (1947) did not transmit Brontë's communicative intention:

\section{ST (1947)}

\section{EL BACHILLER CANSECO}

(1947)

(1). You have killed me-and —iMe habéis matado! ¡Habéis thriven on it, I think. How strong conseguido vuestro objeto! ¿Qué you are!

(II, I, 8-9)

(2). 'I wish I could hold you,' she continued, bitterly, 'till we were both dead!

(II, 1, 9)

(3). He's not a human being,' she retorted; 'and he has no claim on my charity. I gave him my heart, and he took and pinched it to death, and flung it back to me.

\section{(II, 3, 41)}

(4). 'None can tell whether you won't die before us,' I replied. 'It's wrong to anticipate evil.
$(15,183)$

-Quisiera tenerte asido - continuó amargamente - hasta que exhalásemos los dos el último suspiro.

$(15,183)$

— ¡No es un ser humano!-replicó- ¡No tiene corazón! Yo le entregué el mío y él lo cogió, lo estrujó hasta destrozarlo y me lo devolvió.

$(17,197)$

-Nadie puede asegurar que no se muera usted antes que nosotros repliqué-. Es de mal agüero hacer presagios.

$(22,254)$

(II, 8, 172)

We find other examples which refer to the separation of the protagonists. In the first case (example 1), Catherine feels that Heathcliff has taken delight in her death. El Bachiller Canseco (1947) does not follow the ST and provides an 
interpretative translation that moves away from the original. Castillo's solution is, in our opinion, a more accurate one: "de lo que creo que te has regodeado. ¡Qué fuerte eres!". In the same chapter (example 2), Catherine, on her deathbed, does not exempt him from his guilt for their separation and tells Heathcliff that he should die for that. The translator in this case translated the ST freely, exhibiting his qualities as a writer: "hasta que exhalásemos los dos el último suspiro" [until we both took our last breath]. In our judgment "hasta que nos llegara la muerte a los dos" is a right solution.

Lastly, we are witness to another case of free interpretation (example 3). Although Nelly Dean tries to make Isabella see the truth and insists that Heathcliff is a human being, she thinks that he does not deserve her charity, a thought that is not reflected in the TT. The translator makes an equivalence error, since he completely changes the idea of the original text: "iNo tiene corazón!" [He has no heart!]. We suggest the following solution "y no tiene derecho a mi caridad". In the last example (example 4) we can observe some changes in the point of view; this strategy leads him in this case to make a false equivalence error. Nelly's aim is to show Cathy that it is a mistake to anticipate evil. The version moves away from the author's intention. As a right solution we suggest "Está mal anticipar desgracias".

\section{Conclusions}

From the analysis performed in this study, we can draw a series of conclusions. Firstly, the fact that the translator decides on the domestication strategy as the easiest way to circumvent translation problem is noticeable, and, as a result, cultural specificity is lost, which can be seen as failure in the translation of foreign cultural elements in line with the marginal placement of translated literature in the Post-Civil War Period. Secondly, through several solutions applied, we can observe the linguistic void that can be established between the ST and the TT by a translator who is not very familiar with cultural references. Moreover, it is important to note that the translation conflict does not have to be solely and exclusively due to cultural specificity, but that it may be caused by a series of extraneous factors. Among these, we may encounter a lack of competence by the translator (it is important to note that at that time there was no specific training in translation) and the limited use of reference books. As a consequence, the translator resorted to the domestication method as a way to avoid further complications. Furthermore we observe the translator's lack of preparation or the lack of attention paid to specific difficulties that arose at times, which were either resolved by making translation errors, or by sheer omission in the text, which can also be considered an error. 
In the Spanish Post-Civil War period, there was neither specific training for translators nor adequate and easily accessible means to facilitate their work. The post-war situation, both in Spain and in Europe as a whole, and the period of autarchy and exile of intellectuals that Spain was going through did not contribute to alleviate these shortcomings. Ortega Sáez asserts that "a group of men of letters who came across so many obstacles in their attempt to publish in the post-war period that they had no other option but to leave their previous jobs and begin new professions, such as translating, in order to survive. If the situation of the professional translator has almost always been precarious, this condition was much more acute in the decade of the 1940s.

Arturo del Hoyo, for example, a translator working in the Aguilar Publishing House explained that copyright did not exist and that they were only paid for the work done (Rodríguez Espinosa 156). According to Ortega Sáez, Juan GonzálezBlanco de Luaces, "the most prolific translator of post-war Spain" (Juan G[onzález-Blanco] de Luaces 739), on the other hand, carried out his work under great pressure as a means of survival. Moreover, he may have had time restraints imposed by publishing imperatives (Pérez Porras, "Traducciones de la dictadura" 163). This can give us an idea of the limits and precariousness with which the translators coped in their professional labour. Access to sources of information, dictionaries, encyclopaedias and specialised monographs was limited. In the case of El Bachiller Canseco (1947), the translator hid behind a pseudonym for unknown reasons, though we may suspect that precariousness and low esteem of the professional status of the translator was behind this decision.

It is a pity that no biographical data are known about the Bachiller Canseco (1947), for they might have explained many of the numerous omissions in the translation under study. These omissions might be due to the translator's need to carry out several jobs to earn a life, to his job in precarious technical and personal conditions and to time restrictions imposed by publishing imperatives, as in the well-documented case of González-Blanco de Luaces (1942). Although at a first glance, the simplification procedure could be considered to be the result of professional misconduct, other external factors must have played an important role in this respect. Apart from the professional and personal circumstances referred to above, other factors could be put forward, such as the adaptation of a work belonging to an alien polysystem to the conditions of a target polysystem ultimately depending on National Catholicism, autarchy, and dictatorship, and consequently favouring naturalization as the most suitable way of translation. As observed above, the translator opts to comply with the norms of the target culture and the translation, in this connection, responds to "acceptability" as a guiding principle. Undeniably, El Bachiller Canseco’s translation (1947) has occupied an 
important place in the history of the retranslation of Wuthering Heights, but it is at odds with the development of the Spanish social, cultural and literary polysystem in the last forty years. We are in favour of fruitful retranslations, in which the translators detect and correct errors made in previous versions and which reflect the true style of the author and do not contain omissions. For this reason, we think that the recent edition by Edimat (2009) would require proper updating in order to be adapted to the present times.

\section{WORKS CITED}

Alcaraz Varó, E. and Hugues Brian Diccionario de términos jurídicos. InglésEspañol, Spanish-English. 8th. Barcelona: Editorial Ariel, 2005.

Alexander, Christine \& Sellars Jane. The Art of the Brontës. Great Britain: Cambridge University Press, 1995.

Astor Guardiola, Aurora. Proceso a la leyenda de las Brontë. Valencia: Universitat de València, 2006.

Audubon, John James. Ornithological biography, or an account of the habits of the birds of the United States of America. Edinburgh: Adam Black, 18311839.

Barker, Juliet. The Brontës. Londres: Phoenix Press, 1994.

---. "The Haworth Context". The Cambridge companion to the Brontës. 2002. Ed. Heather Glen. Cambridge: Cambridge University Press, 2002. 13-33. https://doi.org/10.1017/CCOL0521770270.

Bewick, Thomas. History of British Birds. Newcastle: Sol. Hodgson for Beilby \& Bewick, 1797-1804.

Bhattacharyya, Jibesh. Emily Brontë's Wuthering Heights (The Atlantic critical studies). Nueva Delhi (India): Atlantic Publisher \& Distributors, 2007.

Blakeborough, Richard. Wit, character, folklore and customs of the north riding of Yorkshire. ( $2^{\mathrm{a}}$ ed.). Salburn-by-the-Sea (United Kingdom): W. Rapp \& Sons, 1911.

Brontë, Anne, Agnes Grey. Trans. El Bachiller Canseco, María Fernanda De Pereda, and Amando Lázaro Ros. Madrid: Aguilar, 1974.

Brontë, Emily and Charlotte Brontë. Wuthering Heights. A novel, by Ellis Bell. In three volumes London: Thomas Cautley Newby, 1847.

Datos Biblioteca Nacional de España. DATOS.BNE.ES (*beta version): Web. 12 Jul. 2017. <https://goo.gl/pvejE8>.

Díaz-Pérez, Francisco Javier. "The translation of humour based on culture-bound terms in Modern Family. A cognitive-pragmatic approach". Eds. Juan José Martínez Sierra \& Patrick Zabalbeascoa Terran. The Translation of Humour / La Traducción del humor. MonTI 19 (2017): 49-7. https://doi.org/10.6035/MonTI.2017.9.2. 
Even-Zohar, Itamar. "The Position of Translated Literature within the Literary Polysystem.” Ed. Itamar Even-Zohar Polysystem Studies (Monographic issue of Poetics Today) 11.1 (1990): 45-51.

Franco Aixelá, Javier. "Culture-specific Items in Translation." Translation, Power, Subversion. Eds. R. Álvarez y C. A. Vidal. Clevedon: Multilingual Matters, 1996. 52-78.

Gil García, Cáliz. Ediciones y traducciones Españolas de Wuthering Heights. Análisis y evaluación. Zaragoza: Universidad de Zaragoza, 1993. PhD dissertation.

Hurtado Albir, Amparo. Traducción y Traductología: Introducción a la Traductología. Madrid: Cátedra, 2001.

Igareda, Paula. "Categorización temática del análisis cultural: una propuesta para la traducción”. Íkala. Revista de Lenguaje y cultura, 16.27 (2011): 11-32. Web. 16 Sep. 2017. <https://goo.gl/fbwU3h>.

Ingham, Patricia. The Brontës (Authors in Context). New York: Oxford University Press, 2006.

Lavín Camacho, Enrique. Ed. Wuthering Heights. Ed. Enrique Lavín Camacho. Madrid: Alhambra, 1984.

López Folgado, Vicente. “Cumbres Borrascosas. Emily Brontë”. Rev. of Cumbres Borrascosas, by El Equipo Editorial. TRANS. Revista de Traductología 15 (2011): 233-236. Web. 19 Jul. 2017. 〈https://goo.gl/aKMj5x>.

---. "Las traducciones de Wuthering Heights: plagios flagrantes". Alfinge. Revista de Filología 23 (2011): 143-162. Web. 11 Sep. 2017. <https://goo.gl/kKx9DS>.

Luque Nadal, Lucía. "Los culturemas: ¿unidades lingüísticas, ideológicas o culturales?.” Language Design 11 (2009): 93-120. Web. 14 Sep. 2017. <https://goo.gl/fXoKSb>.

Marsh, Nicholas. Emily Brontë: Wuthering Heights. Londres: MacMillan, 1999. https://doi.org/10.1007/978-1-349-27724-7

Molina Martínez, Lucía. Análisis descriptivo de la traducción de los culturemas árabe-español. Universitat Autònoma de Barcelona: Barcelona, 2001. PhD dissertation. Web. 22 Jul. 2017. 〈https://goo.gl/rLyYyq>.

Newmark, Peter. A textbook of translation. New York: Prentice-Hall International, 1988.

Ortega Sáez, Marta. "Juan G[onzález-Blanco] de Luaces: el traductor desconocido de la posguerra española". ARBOR. Ciencia, Pensamiento y Cultura 185 (2009): 1339-1352. Web. 9 Jul. 2017. 〈https://goo.gl/UpJyrV〉.

---. Traducciones del franquismo en el mercado literario español contemporáneo: el caso de Jane Eyre de Juan G. de Luaces. Universitat de Barcelona, Barcelona, 2013. PhD dissertation. Web. 5 Jul. 2017. <https://goo.gl/9R9ppK>.

---."The Role and Functon of the Translator in post-Civil War Spain: Juan G. de Luaces", Actas del III Congreso Internacional de la Asociación Ibérica de Estudios de Traducción e Interpretación. La traducción del futuro: mediación lingüístca y cultural en el siglo XXI. Barcelona: PPU. Vol. 1 (2008): 283-294. Web. 23 Jul. 2017. <https://goo.gl/X1AzdX>. 
Paddock, Lisa \& Rollyson, Carl. The Brontës. A to Z: the essential reference to their lives and work. New York: Facts On File, 2003.

Pajares Infante, Eterio. "Traducción y censura: Cumbres borrascosas en la dictadura franquista". Traducción y censura en España (1939-1985). Estudios sobre corpus TRACE: cine, narrativa, teatro. Bilbao: Universidad del País Vasco and Universidad de León: Raquel Merino Álvarez, 2007. 49-104. Web. 14 September 2017. <https://goo.gl/UWnbtJ>.

Pérez Porras, Ana. Análisis comparativo de cinco traducciones de Wuthering Heights, de Emily Brontë. Sevilla: Universidad Pablo de Olavide, 2015. PhD dissertation. Web. 7 July 2017. <https://goo.gl/dPpyNi>.

---. "Traducciones de la Dictadura Franquista en el mercado editorial contemporáneo. Cumbres Borrascosas de Juan G. De Luaces". Escritoras periféricas y adaptaciones de textos, Volume 5. Sevilla: Benilde, 2017. 148-167.

Readers's Guide to Wuthering Heights, The. Web. 22 Sep. 2017. $<$ https://goo.gl/VrXiuh>.

Rodríguez Espinosa, Marco. "Editores y traductores difusores de la historia literaria. El caso de Arturo del Hoyo en la editorial Aguilar". TRANS. Revista de Traductología 2 (2007): 153-164. Web. 25 Jul. 2017 <https://goo.gl/GgBR7o>.

Santoyo, Julio César. "A propósito del término "Translema"”. Tendencias actuales en las aplicaciones de la lingüística. Actas del Primer Congreso Nacional de Lingüística Aplicada: Murcia. Madrid: SGEL and Universidad de Murcia, 1983: 255-275. Reprinted in Babel 32, 1 (1986): 50-55.

---. "Plagio en las traducciones inglés-español". Atlantis: Revista de la Asociación Española de Estudios Anglo-Norteamericanos 2.1 (1980): 60-64. Web. 5 Jul. 2017. 〈https://goo.gl/saz2jx >.

Simpson, J.A. and E.S.C. Weiner. Eds. The Oxford English Dictionary. 2nd ed. Oxford: Clarendon Press, 2004.

Spear, Hilda D. Wuthering Heights by Emily Brontë: Macmillan Master Guides. London: Palgrave Macmillan, 1985. https://doi.org/10.1007/978-1349-07421-1

Tello Fons, Isabel. La traducción del dialecto: análisis descriptivo del dialecto geográfico y social en un corpus de novelas en lengua inglesa y su traducción al español. Castellón: Universitat Jaume I, 2011. PhD dissertation. Web. 7 Sep. 2017. 〈https://goo.gl/ibUqvX〉.

Thompson, F.M.L. English Landed Society in the Nineteenth-Century. London: Routledge \& Kegan Paul, 1963.

Thompson, Wad. "Infanticide and sadism in Wuthering". PMLA 78.1 (1963): 6974. Web. 8 Jul. 2017. 〈https://goo.gl/eU8CeX〉.

Toury, Gideon. Descriptive Translation Studies and beyond. Revised edition (2). Philadelphia, NL: John Benjamins Publishing Company, 1995.

Valero Garcés, Carmen. Modelo de evaluación de obras literarias traducidas: The Scarlet Letter/La Letra Escarlata de Nathaniel Hawthorn. Bern: Peter Lang, 2007. 
Venuti, Lawrence. The Translator's Invisibility: A History of Translation. London and New York: Routledge, 1995. Web. 25 Jun. 2017. $<$ https://goo.gl/4FeqoN>.

\section{TRANSLATIONS}

Caballero, Andrés (Trans.). Cumbres Borrascosas. Barcelona: Vives, 1945.

Castillo, Rosa (Trans.). Cumbres Borrascosas. Ed. Paz Kindelán. Madrid: Cátedra, 1996.

Conde Vélez, Luis (Trans.). Cumbres Borrascosas. Barcelona: Bruguera, 1945. D'Amonville Alegría, Nicole (Trans.). Cumbres Borrascosas. Barcelona: Random House Mondadori, 2012.

Durán, Fernando (Trans.). Cumbres Borrascosas. Barcelona: Juventud, 1944.

El Bachiller Canseco (Trans.). Cumbres Borrascosas. Madrid: Aguilar, 1947.

El Equipo Editorial (Trans.). Cumbres Borrascosas. Madrid: Edimat, 2009.

González-Blanco de Luaces, Juan (Trans.). Cumbres Borrascosas. Madrid: Destino, 1942.

Pérez Ferrero, Miguel (Trans.). Cumbres Borrascosas. Madrid: La Nave, 1942.

Zengotita, Javier (Trans.). Barcelona: Reguera, 1944. 